\title{
MOTHER'S FIRST EXPERIENCE IN ASSISTING CHILDREN WITH ACUTE LYMPHOBLASTIC LEUKEMIA WHO IS UNDERGOING CHEMOTHERAPY
}

\section{Pengalaman Pertama Ibu Mendampingi Anak Penderita Acute Lymphoblastic Leukemia Menjalani Kemoterapi}

Dwi Novrianda*, Fini Alfianita**

*Lecturer of Faculty of Nursing University of Andalas

**Student of Faculty of Nursing University of Andalas

Email: dwinov_82@yahoo.co.id

\begin{abstract}
ABSTRAK
Pendahuluan. Acute lymphoblastic leukemia (ALL) merupakan penyakit keganasan yang paling banyak ditemukan pada anak. Pengobatan utama pasien ALL adalah kemoterapi dalam waktu lama sehingga dapat mempengaruhi kehidupan ibu sebagai pengasuh utama. Penelitian ini bertujuan untuk mengeksplorasi, memahami, dan memberi makna dan arti pengalaman pertama ibu mendampingi anak penderita ALLmenjalani kemoterapi fase induksi. Metode. Penelitian ini merupakan penelitian kualitatif dengan pendekatan fenomenologi. Enam orang partisipan diambil secara purposive sampling berpatisipasi dalam wawancara. Alat pengumpulan data dalam penelitian ini adalah pedoman wawancara dan catatan lapangan. Hasil wawancara ditranskrip secara verbatim dan dianalisis dengan menggunakan metode Collaizi (1978). Hasil. Enam tema ditemukan dalam penelitian ini yaitu: 1) mengalami respon emosional, 2) mengalami gangguan fisik, 3) mencari informasi, 4) mengalami pengalaman spritual, 5) mengalami beban ekonomi, dan 6) pentingnya dukungan. Diskusi. Disarankan perawat menyediakan asuhan keperawatan pada ibu yang mendampingi anak dalam kemoterapi untuk pertama kalinya, memberikan intervensi terkait emosional, fisik, dukungan, dan spiritual. Diperlukan juga pemberian informasi diawal kepada ibu tentang kemoterapi.
\end{abstract}

Kata kunci:Pengalaman pertama ibu, kemoterapi, fase induksi, anak leukemia limfoblastik akut

\begin{abstract}
Introduction. Acute Limfoblastic Leukemia (ALL) is a malignant disease which mostly found in children. The main treatment of ALL is chemotherapy for a long time, so it affects their mother life as the primary caretaker. This research aimed to explore, understand, and give the meaning of mother's first experience in assisting children with ALL that was undergoing chemotherapy: the induction phase. Method. This research was a qualitative research by using phenomenological. Six participants were taken by using purposive sampling that participated in interview. In-depthinterviews and field note were used to collect data. The result of the interview was transcribed verbatimly and analyzed by Collaizi method. Results. There was six main themes that found in this research including:1) undergoing emotional response, 2) undergoing physical impaired, 3) seeking information, 4) undergoing a spiritual experience, 5) undergoing an economic burden, and 6) the importance of support. Discussion. It suggests that nurses provided nursing care to mother that assisting the children in chemotherapy at the first time like giving intervention concerned emotional problem, physical, and spiritual. It also gives earlier information for mother about chemotherapy.
\end{abstract}

Keywords: mother's first experiences, chemotherapy, induction phase, acute lymphoblastic leukemia's children

\section{INTRODUCTION}

Leukemia is a cancer of the blood vessel tissue and the most common found in child.21,1 Leukemia that occurs generally Acute Lymphoblastic Leukemia (ALL). The main treatment used is chemotherapy because of leukemic cells from patients with leukemia are usually quite sensitive to chemotherapy at the time of diagnosis (Rodolph, 2007). Chemotherapy was repeated and regular maintenance are given in combination, the duration of treatment for two to three years for patients with ALL (Gamayanti, 2007).
The first phase of chemotherapy that is given to children with leukemia is the induction phase. It's very strict and sometimes complications can be quite serious and threatening (American Cancer Society, 2013). Ariawati et al (2007) reported that the administration of chemotherapy ALL in the induction phase and central nervous system prophylaxis showed various acute toxicity, such as nausea and vomiting that occurs at most once administration of methotrexate dose of $1 \mathrm{~g} / \mathrm{m} 2$ and then after administration of methotrexate intratekal. Further research Umiati et al (2010) 
also reported that children with cancer receive treatment procedures are long and the side effects of treatment. Therefore, children with leukemia who undergo chemotherapy need to be accompanied by parent as the primary caregiver for support and care in dealing with the effects of treatment.

The role of primary caregiver is usually dominated by a mother because of his responsibilities as a care provider of child (Gamayanti, 2012). Low quality of life of children as a result of disease and chemotherapy can cause stress for family (Tamayo, 2010). Primary stressors that affect the quality of life of mothers of children with diseases including cancer, the treatment process, the demands of parenting, the weakness of the patient, the duration and disease's recurrence (Bayat, 2008). First experience of mothers who accompany children undergoing chemotherapy can affect the quality of life of the mother. This is consistent with research of Klassen et al. (2008) reported that parents who have children with cancer showed low quality of life. This study aimed to provide an overview of how mother's first experience in assisting children with acute lymphoblastic leukemia undergoing chemotherapy in induction phase.

\section{METHOD}

This type of research was a qualitative research with descriptive phenomenology approach. Data collection methods used indepth interviews. The numbers of participants in this study were 6 people. Selection of informants in this study used purposive sampling technique. The participants in this study were participants who had inclusion criteria: 1) the mother has a child who was diagnosed with ALL; 2) the mother of a child who was undergoing chemotherapy: induction phase and already getting intrathecal chemotherapy; 3) The mother of a child who had completed chemotherapy: induction phase or has just entered a phase of consolidation; and 4) willing to be a participant. As for exclusion criteria was mothers of children who have completed the induction phase of chemotherapy but continued reinduction phase.
Researchers establish itself as a tool to collect data. In addition, the researchers also used the interview guide, stationery and voice recorder / phone to improve the accuracy of the data. Analysis of the data used Colaizzi method (Speziale, 2007).

\section{RESULT}

Based on key words that were analyzed through verbatim transcript obtained 16 categories produced 9 sub-themes and subthemes were obtained 6 themes that describe the meaning of mother's first experience assisting children with leukemia who undergoing chemotherapy: induction phase. The themes obtained were: 1) experiencing emotional response, 2) physical disorders, 3) search for information, 4) experienced a spiritual experience, 5) experienced an economic burden, and 6) the importance of support.

\section{Experiencing Emotional Response}

In this study, participant experienced negative emotional responses such as anxiety, fear, and stress accompany children when first induction phase of chemotherapy. Anxiety experienced by the participants in accordance with the following statement:

“... Sometimes anxiety ...” (P1)

“... Firstly, it worries I just can cry...” (P2).

In this study, participants also experience fear when assist children undergoing chemotherapy: induction phase for the first time. This was in accordance with the statement of the following participants:

“... Fear of the consequences might be vomiting, fever later ...” (PI).

“... The methotrexate was injected into her spine, fear ... "(frown) (P4).

“... Yes, fear of the side effects ...” (P5).

Furthermore, participants experienced stress when accompany children in first induction phase of chemotherapy. This was in accordance with the statement of the following participants: 
“... the first CPZ was a bit stressful, I didn't understand..." (P2).

“... After giving metotreksat, it was stressful ...” (P4).

In addition to the negative emotional, participants also said they had a positive emotional response. It happen many positive changes that occur in children. This was in accordance with the statement of the following participants:

“... Sometimes I feel happy when I see his development ...” (PI).

“... My son ate better, was able to sleep, I was like that, I were very happy as long as 6 weeks of drugs until now ... "(P2).

\section{Experiencing Physical Disorders}

In this study, participants said they could not sleep at the first time of induction phase of chemotherapy. This was in accordance with the statement of the following participants:

“...I didn't want to eat, can't sleep, I just thought of my child ..." (P3).

“... sleepless, I often surprised, as the stress that is so..." (P6).

In this study, participants told they can't eat at the first time of induction phase. This was in accordance with the statement of the following participants:

“... Yes, I can't eat...” (P3).

“...I become thin, reluctant to eat ...” (P6).

\section{Finding Information}

In this study, participants stated that they are asking and looking for information about chemotherapy for health workers, especially doctors and doctors of a given protocol. This was in accordance with the statement of the following participants:

"...Firstly, I didn't understand, then the doctor explained...” (P4).

"...Protocol provided by the doctor, that is undertaken...” (P6).
In this study, participants also stated that they are asking and looking for information about chemotherapy to people who are already experienced. This was in accordance with the statement of the following participants:

"... Many of my friends ask about how the chemotherapy is, what is the medicine?..." (P3).

"... Before entering the isolation room, I always ask people who have undergone..." (P6).

\section{Experiencing Spiritual Experience}

One participant revealed that prayer can make she feels calm. This was in accordance with the statement of the following participants:

“... Yes, prayer, surrender to God, make me calm...” (P4).

Two other participants had no choice reveals nothing but do chemotherapy in children, so they go and accept everything. This was in accordance with the statement of the following participants:

“... Give to the God ...” (P5).

“... I just live it...” (P6).

\section{Experiencing the Economic Burden}

In this study, 2 participants give meaning "to experience an economic burden" during the induction phase of chemotherapy accompany children. Both participants felt that the greater economic pressure to assist children in the induction phase of chemotherapy due to chemotherapy induction phase requires the child to remain in the hospital for six weeks. It makes the cost of the needs of mothers who accompany children during hospitalization increased compared to the cost of the needs at home. This was in accordance with the following statement:

"...cost in hospital larger than at home..." (P2).

"...the biggest cost is caring for child in hospital...”(P4). 


\section{The Importance of Support}

In this study, participants gave the meaning of "the importance of support" when the first time of induction phase. Participants referred to the importance of support in this study a family of informational support in giving the decision to undergo chemotherapy in children. This was in accordance with the statement of the following participants:

“... Everyone support for this chemotherapy ...” (P5).

“... All of family gives endorsements that are the right way..." (P6).

\section{DISCUSSION}

Participants in this study indicated that information from others about chemotherapy procedures that tend to provide body injury in children and some of the side effects of chemotherapy, making them worry something bad will happen to their children. Parents tend to feel that medical treatment is traversed by an act endangering children so parents tend to feel anxious and sensitive to medical procedures to be performed on child (Martin, 2007).

In addition to anxiety, participants also said that they felt afraid of the procedure and the chemotherapy side effects were performed on children. Fear responses were also seen on the faces of participants who frowned when told about the experience of fear. This is consistent with study of Bayat et al (2008) said parents experienced fear with the treatment of children that is not working well or ineffective.

Stressors can affect an increased risk of stress in families with children who suffer from chronic diseases. In accordance with the results of interviews that have been done that mothers feel stressed when they accompanied their son to undergo a treatment process in which the procedure of the treatment they provide body injury to the child and the impact of such actions made after the child is unconscious within a few hours because it caused from the drug pushers.

Aritonang (2008) mention that routine medical treatment and action inflicting pain on children who suffer from the chronic diseases.
Family especially mothers often feel scared and did not have the heart. Profound sadness always follow everytime when see the pain of her son. This can lead to stress to the family.

In addition to experiencing a negative emotional response, participants also experienced a positive emotional response that is happy because the child's condition is getting better. During the induction phase of chemotherapy, child undergone many positive changes. Response happy look of the entire face when participants perceived positive changes, participants also seemed enthusiastic when telling the positive changes.

Othman et al reported that parental anxiety will decrease after the child reported improved conditions. According to investigators, the pleasure was felt by the participants due to the feeling of anxiety decrease. The condition of child has experienced a change like increased appetite, lethargy and other symptoms decreased (Othman, 2011).

Furthermore, physical disturbance was experienced by mother such as sleep disturbance and loss of appetite. This can be seen in the faces of the participants have eye bags and black, so it is obvious that the participants lack of sleep. Participants have trouble sleeping and loss of appetite due to anxiety, fear and stress felt by the mother when accompanying children undergoing medical procedures tend to provide bodily injury to the child. Mother can't sleep in peace as well as the demand to always pay attention to the child in each treatment. This is consistent with research Elcigil and conk (2010) is reported that the mother revealed a range of physical health problems such as insomnia and loss of appetite caused by the stress felt by the mother during the treatment of children with cancer.

In addition, participants stated that they ask and look for information about chemotherapy for health workers is the Doctor. Two participants did not actively do it but they only receive information from the explanation and chemotherapy protocols provided by the doctor when her first chemoteraphy, and 5 participants stated that they are asking and looking for information about chemotherapy 
to people who are already experienced. They do actively to ask questions directly to mothers who have experienced and even directly see how the children who had prior chemotherapy.

This is consistent with research Bjork et al (2005), which states that during the treatment of cancer in children, family members realize that they need information, and they focus on what they are looking for, than they thought of the difficulty in finding the information needed. In other words, the family will find information anywhere until their curiosity is met.

According to the JLS Foundation of parents who join the JLS Foundation must equip themselves with knowledge and information that is sufficient and appropriate to prevent the occurrence of errors and omissions in the care of parents to children (Aritonang, 2008). Doctors, nurses, therapists and people who have experienced a source of information right. Sometimes kids will ask about the condition of her illness. To that end, parents need to learn good technique in answering the question of children so as not to cause concern to their children. Things like this will be known when the parents are going to ask questions and share with those who are already experienced.

Then participants give meaning "spiritual experiences". One participant stated that the participants found the serenity to draw closer to God, namely by way of worship like prayer. Researchers also look around the child's bed are prayer materials from the participants, it also proves that the participants had to draw closer to God to find peace during chemotherapy accompany children.

According to Potter \& Perry (2005) that involvement in religious activities is one way to discover the meaning of the events that make it difficult or test the spiritual development people. Furthermore, 2 participants also expressed resignation and have received their child including all medical procedures that will be undertaken for their children. This is because they realize that chemotherapy is the only way to treat only children. According to researchers, in order to reduce the perceived pressure, surrender is one right way to be able to survive the conditions. Furthermore, the perceived economic burden caused by the mother during the induction phase of the child must be settled at the hospital to have a policy. Although government can help the cost of chemotherapy treatment at the hospital. However, the cost for transportation and living expenses for hospital borne independently by participant. Families caring for children with cancer spend sizeable during treatment and follow treatment phase (Midema, 2008; Mostert, 2008).

Participants also gives the meaning of "the importance of support" when accompanying a child undergoing chemotherapy induction phase in the department of Dr. M Jamil Padang. Support required by participants sourced from family support in providing advice when making decisions for chemotherapy in children. Bjork et al (2009) mentioned that the support of the family to be important for families undergoing cancer treatment in child.

The presence of maternal experience to assist children during chemotherapy-related emotional problems, physical, and spiritual support should be the focus of attention of nurses in providing information, advocacy, and support.

\section{CONCLUSION}

There was six main themes that found in this research including:1) undergoing emotional response, 2) undergoing physical impaired, 3) seeking information, 4) undergoing a spiritual experience, 5) undergoing an economic burden, and 6) the importance of support.

\section{RECOMMENDATION}

It suggests that nurses provide nursing care to mother that assisting the children in chemotherapy at the first time like giving intervention concerned emotional problem, physical, and spiritual. It also gives earlier information for mother about chemotherapy. 
Mother's First Experience in Assisting Children (Dwi Novrianda dan Fini Alfianita)

\section{REFERENCES}

American Cancer Society. Treatment of Children with Acute Lymphocytic Leukemia. 2013. [cited 22 April 2014]. http://www.cancer.org/cancer/ leukemiainchildren/detailedguide/ childhood-leukemia-treating-childrenwith-all.

Ariawati K, Windiastuti E, Gatot D. 2007. Toksisitas Kemoterapi Leukemia Limfoblastik Akut pada Fase Induksi dan Profilaksis Susunan Saraf Pusat dengan Metotreksat 1 Gram. Sari pediatri, 2007; 9(4): 252-258.

Aritonang MV. Pengalaman Keluarga dengan Anak yang Menderita Penyakit Kronis. 2008. [cited 10 Maret 2014]. http://repository.usu.ac.id/ bitstream/123456lontar.ui.ac.id/file? file $=$ digital $/ 20280932$.

Bayat M, Erdem E, Kuzucu EG. 2008. Depression, Anxiety, Hopelessness, and Social Support Levels of the Parents of Children with Cancer. Journal of Pediatric Oncology Nursing, 2008; 25(5): 247-253.

Bjork M, Wiebe T, Hallstrom I. 2005. Striving to Survive: Families' Lived Experiences When a Child is Diagnosed with Cancer, Journal of Pediatric Oncology Nursing, 2005; 22(5): 265-275.

Bjork M, Wiebe T, Hallstrom I. 2009. An Everyday Struggle-Swedish Families Lived Experiences during A Child's Cancer Treatment, Journal of Pediatric Nursing, 2009; 24(5): 423-432.

Elcigil A, Conk Z. 2010. Determining the Burden of Mother with Children Who Have Cancer, Dokuz Eylul Universitesi Hemsirelik Yuksek Okulu Elektronik Dergisi, 2010; 3(4): 175-181.

Gamayanti P, Rakhmawati W, Mardhiyah A, Yuyun S. 2012. Gambaran Kualitas Hidup Keluarga dalam Merawat Anak dengan Leukemia yang Menjalani Kemoterapi di RSUP Dr. Hasan Sadikin Bandung,. Indonesian Journal of Cancer, 2012; 6(1): 13-20.
Klassen AF, Klaassen R, Dix D, Sung L. 2008. Impact of Caring for A Child with Cancer on Parents' Health-Related Quality of Life,. Journal of Clinical Oncology, 2008; 26(36): 5884-5889.

Martin AL, McGrath PA, Brown SC, Katz, J. 2007. Anxiety Sensitivity, Fear of Pain and Pain-Related Disability in Children and Adolescents with Chronic Pain, The Journal of Canadian Pain Society, 2007; 12(4): 267-272.

Miedema, B, Easley J, Fortin P, Mathews M. 2008. The Economic Impact on Families When A Child is Diagnosed with Cancer,. Current Oncology, 2008; 15(4): 173-178.

Mostert S, Sitaresmi MN, Gundy CM, Veerman AJP. 2008. Parental Experiences of Childhood Leukemia Treatment in Indonesia. J Pediatr Hematol Oncol, 2008; 30(10): 738-743.

Othman A, Mohamad N, Hussin ZA.2011. Factors Related to Parental Wellbeing in Children with Cancer, International conference on social science and humanity, 2011; 5: 255-260.

Potter PA, Perry AG. 2005. Buku Ajar Fundamental Keperawatan: Konsep, Proses, dan Praktik. Edisi 4 Volume 2. Alih bahasa: Renata Komalasari. Jakarta: EGC

Rudolph AM, Hoffman JIE, Rudolph CD. 2007. Buku Ajar Pediatri Rudolph. Edisi 20 Volume 2. Alih bahasa: A. Samik \& Sugiarto. Jakarta: EGC

Speziale HJS, Carpenter DR. 2007. Qualitative Research in Nursing: Advancing The Humanistic Imperative. Fourth edition. Lippincott: Philadelphia.

Tamayo GJ, Broxson A, Munsell M, Cohen MZ. 2010. Caring For The Caregiver. Oncology nursing forum, 2010; 37(1): E50-E57.

Umiati M, Rakhmawati W, Simangungsong B, Tehuteru ES. 2010. Gambaran Kualitas Hidup Anak Usia 6-18 Tahun yang Menjalani Kemoterapi di Rumah Sakit Kanker "Dharmais", Jakarta Barat. Indonesian Journal of Cancer, 2010; 4(2): 45-48. 